\title{
STRENGTHENING LEGAL EDUCATION AND JUDICIAL TRAINING IN THE MALDIVES: A CASE STUDY
}

\author{
Suresh Nanwani* and A. Mohaimin Ayus**
}

\begin{abstract}
The article discusses the law and policy reform activities carried out by the Asian Development Bank with its focus on countries in the Asia-Pacific region, and the legal interventions which impact upon citizens, private sector, and state institutions. The technical assistance seeks to strengthen legal education and judicial training in the Maldives. Under this project, the country's recently-established Faculty of Shariah and Law was strengthened to provide legal education to students wishing to study shariah and law and obtain a law degree. Also, judicial training was provided to the country's judges and island magistrates to carry out their duties in hearing cases and applying law and court procedures. The article postulates the need to take into account and address the local needs, context
\end{abstract}

Associate Secretary, Compliance Review Panel, Asian Development Bank.

Associate Professor, Ahmad Ibrahim Kulliyyah of Laws (AIKOL), International Islamic University Malaysia (IIUM).

The authors wish to thank Professor Leslie J. Moran and Ms. Marie Antoinette Virtucio for their contributions in reviewing an earlier version of this article, and Ms. Josefina C. Miranda for her research assistance. 
and sensitivities, rather than merely transplanting a western legal system which would otherwise not work for the country and its peoples where shariah is an important legal system. It also highlights the need to adopt a flexible approach in addressing problems and challenges rising during project execution to ensure realization of effective results. The article offers some thoughts and reflections on the lessons learnt for consideration in any developing country on a similar project to strengthen legal education and judicial training.

\section{INTRODUCTION}

This article provides a case study of a project funded by the Asian Development Bank (ADB) ${ }^{1}$ to strengthen legal education and judicial training in the Maldives (Project) ${ }^{2}$ under a technical assistance (TA) grant of US\$995,000 to the government of the Republic of Maldives over the years 2000 to early 2004. It offers some thoughts and reflections on lessons learnt in the design and execution of a legal education and judicial training project, in the absence of publications on evaluations on these initiatives carried out by multilateral development banks, including ADB. Under this Project, the recently established Institute of Shari'ah and Law (ISL) ${ }^{3}$ was strengthened to deliver legal education and judicial training. The Project provided for related activities such as organizing

$1 \quad$ ADB is a multilateral development financial institution owned by 66 member countries (as of 18 December 2006), 47 from the Asia and Pacific region and 19 from other parts of the world. Its mission is to help its developing member countries reduce poverty and improve the quality of life of their citizens.

ADB. 1999. Technical Assistance to the Republic of Maldives for Strengthening Legal Education and Judicial Training (TA No. 3389MLD).

$3 \quad$ ISL was established in August 1999 and made part of the Maldives College of Higher Education (MCHE) which consolidates and coordinates the administration and academic programs of postsecondary education institutes in the country. In 2001, ISL was renamed as the Faculty of Shari'ah and Law (FSL). For purposes of this article, FSL is typically used instead of ISL. 
fellowships for a cadre of professional academic staff at the fledgling institute, together with curriculum development, establishing a linkage arrangement on further legal education with a suitable foreign institution, and the preparation of a judicial bench book (practice manual) for judges and island court magistrates in the country.

\section{LAW AND POLICY REFORM ACTIVITIES AT THE ASIAN DEVELOPMENT BANK}

Law and policy reform (LPR) activities carried out by the ADB refer to interventions in areas of law reform: legal and judicial policy reform, or legal empowerment initiatives which impact upon citizens, private sector business, and state institutions. ADB's LPR activity can be characterized in two respects: general and specific. The general role is played by the institution's lawyers in its legal department who provide legal analysis and diligence as team members, when the bank designs and administers a project in its lending operations, for both public and private sectors. This includes formulating loan covenants and conditions for legal agreements, and carrying out analysis and diligence at various stages, from project design to project approval, execution and completion.

The specific role, which is the focus of this article, is the activity carried out by the institution's lawyers and other staff in designing LPR projects. This LPR activity is distinct from the failed "law and development movement" of the 1960s and 1970s and is referred to the current or "second stage" movement led primarily by multilateral development banks, including $\mathrm{ADB}$, since the 1990s to improve the legal and judicial environment in developing countries. The "law and development movement" was primarily aimed at the reform of legal education in developing countries, premised on the need for these countries to modernize their courts and legal systems to respond to the pressures of poverty and underdevelopment. This movement was a by-product of assistance by the United States government, international agencies, and private foundations working with governments and legal institutions in the third world. ${ }^{4}$ The activities carried out have been summarized as "all

$4 \quad$ David M. Trubek and Marc Galanter, "Scholars in Self-Estrangement: Some Reflections on the Crisis in Law and Development Studies in the United States,” (1974) Wisconsin Law Review, pp. 1062 -1102, p. 1063. 
rather heady and glamorous." ${ }^{5}$ With the drying up of assistance, the movement fizzled in the 1970s and was largely a failure though some have viewed success in limited cases. ${ }^{6}$

The "law and development movement" has been best described as "largely a parochial expression of the American legal style" which did not take into account that the societies of the developing countries had different legal traditions and orders. ${ }^{8}$

In 1995, ADB's legal department, the Office of the General Counsel, established a group of lawyers with expertise on law and development. This group was strengthened in 1999 with the creation of a special practice group on law and policy reform. ${ }^{9}$ ADB strengthened its LPR activities with its adoption of a governance policy ${ }^{10}$ in 1995 which

5 John Henry Merryman, "Comparative Law and Social Change: On the Origins, Decline \& Revival of the Law and Development Movement." (1977) 25 American Journal of Comparative Law, pp. 457-491, p. 458. Hugo Frûhling, "From Dictatorship to Democracy: Law and Social Change in the Andean Region and the Southern Cone of South America" in Many Roads to Justice - The Law-Related Work of Ford Foundation Grantees Around the World, edited by Mary McClymont and Stephen Golub, the Ford Foundation (February 2000), pp. 56-57, where the movement for law school reform produced more enduring impact at the Catholic University Law School of Peru.

7 John Henry Merryman, supra n. 6, p. 479.

8 David M. Trubek and Marc Galanter, supra n. 5; David M. Trubek, "Toward a Social Theory of Law: An Essay on the Study of Law and Development," (1972) 82(1) The Yale Law Journal: pp. 1-50; ADB. 1998. "A Review of the Law and Development Activities of the Asian Development Bank;” Eisuke Suzuki, "Law and Policy in Development: Lessons from the Asian Development Bank's Assistance in Asia," unpublished paper presented at the Canadian Bar Association Annual Conference on International Legal Technical Assistance Workshop in Edmonton, Canada on 22 August 1999. The practice in other multilateral development banks (MDBs), such as the World Bank, European Bank for Reconstruction and Development, African Development Bank, and Inter-American Development Bank, is similar where their legal departments also play a leading role by establishing units or teams tasked to carry out LPR activities.

10 Athttp://www.adb.org/Documents/Policies/Governance/govpolicy.pdf (last visited 18 December 2006). 
underscored the importance of these activities in promoting governance in the bank's lending operations through the four elements of accountability, predictability, participation, and transparency.

In the late 1990s, ADB carried out a review ${ }^{11}$ of its law and development activities and found that the activities had been discrete and episodic in response to particular issues identified in ADB's project and program loans and that the law and development strategy should adopt a systemic approach to law reform and its relationship to economic development. ${ }^{12}$ The review highlighted the following three areas for ADB to focus in pursuing this approach: capacity building and institutional strengthening such as continuing legal education for legal professionals, including government officials focusing on newly enacted laws and regulations for a market economy; strengthening secondary institutions such as law schools and law faculties; and supporting the institutional framework for the rule of law such as assisting anticorruption agencies.

From 1995 onwards, ADB has adopted a systemic approach to legal reform to promote "economic development"13 and to reduce poverty, the overarching goal of ADB. ${ }^{14}$ Over the past decade, ADB has engaged in more than 400 LPR-related TA and loan projects for its developing member countries. ${ }^{15}$ The LPR activities include the following five areas: legislative and institutional reforms for the government, its legal services or the judiciary; making judicial systems work better; raising transparency and dissemination of information in these countries and building capacity for undertaking legal reforms; capacity building and institutionalizing

$11 \quad$ ADB. 1998. "A Review of the Law and Development Activities of the Asian Development Bank,” (published in February 1998). Ibid., paragraphs 43 and 77.

13 Article 1 of the Agreement Establishing the Asian Development Bank (ADB Charter) at http://www.adb.org/ Documents/Reports/Charter/ charter.pdf specifies the purpose of the bank which is to "contribute to the acceleration of the process of economic development" of the institution's developing member countries (last visited 18 December 2006).

14 ADB. 2005. Law and Policy Reform at the Asian Development Bank, Foreword by Arthur M. Mitchell, General Counsel, ADB at http:// www.adb.org/documents/reports/law-policy-reform/foreword.pdf, pp. 7-8 (last visited 18 December 2006).

$15 \quad$ Ibid., p. 8. 
training for government institutions and officials, judges, and lawyers; and researching in strategic areas and convening key actors from these countries to consider findings. ${ }^{16}$

One main feature of ADB's LPR activities is the establishment of legal training institutions or providing a framework to institutionalize legal and judicial training. These activities have been carried out in Vietnam, Mongolia, and Maldives from 1997 to the present. In Vietnam, ADB provided a TA for US $\$ 1,200,000$ to the government for retraining government legal officers. ${ }^{17}$ Under this TA, continuing legal education through an intensive training program would be provided to Vietnamese legal officers and lawyers, particularly those in government agencies, so that they can function better in a market-oriented economy. This TA also involved training of trainers. ${ }^{18}$ The TA project period was expected to be 3 years though it took 2 more years to complete due to delay in the implementation of the retraining program and the production of a Vietnamese law book not included in the original design, and to allow flexibility in implementation for capacity building of the project executing agency. ${ }^{19}$

In Mongolia, ADB has provided 2 TA grants to retrain professionals in a market economy, one in 1997 and the other in 2002. ${ }^{20}$

16 Law and Policy Reform in Asia and the Pacific: Ensuring Voice Opportunity \& Justice (2005) at http://www.adb.org/documents/ Brochures/Voice-Opportunity/voice-opportunity.pdf, p. 6 (last visited 18 December 2006).

ADB. 1997. Technical Assistance to the Socialist Republic of Viet Nam for Retraining Government Legal Officers. (TA No. 2853-VIE). The TA completion report for this project is at http://www.adb.org/ documents/ TACRs/VIE/ tacr vie 2853.pdf (last visited 18 December 2006). This report typically summarizes the experiences of ADB and the project executing agencies and indicates the lessons learned to improve ongoing or future projects.

18 A cadre of Vietnamese legal trainers forming a full-time faculty of the Legal Professionals Training Center at the Ministry of Justice to provide retraining to Vietnamese legal officers and lawyers.

19 These reasons are given in the TA completion report for this project, at http://www.adb.org/documents/TACRs/ VIE/tacr vie 2853.pdf (last visited 18 December 2006).

20 ADB. 1997. Technical Assistance to Mongolia for Retraining Legal Professionals in a Market Economy. (TA No. 2967-MON). 
The first TA project for US $\$ 1,000,000$ assisted the Mongolian government to establish a legal research center and develop a retraining program in continuing legal education for Mongolian lawyers to apply legal principles in commercial laws and regulations including specialized training for judges and prosecutors. This 3-year TA project took 4 more years to complete, due to delays in selecting trainers and establishing the legal resource center. ${ }^{21}$ The second TA project for US\$150,000, building on the successful completion of the first TA project which trained 500 legal professionals, strengthens the training program provided by the learning research center to develop additional programs and extend training programs to remote provinces to cover 250 more Mongolian lawyers. ${ }^{22}$ As of 18 December 2006, the second TA project is still ongoing.

In the case of the Maldives, ADB has provided 2 TAs to date, the first was in 1997 and the second in 1999. The first TA for $\$ 150,000$ was to assist the government to identify measures to improve lawmaking, court administration and legal education, including steps for setting up a system to provide continuing legal education for judges, court administrators, government and private lawyers. ${ }^{23}$ This TA was carried out for about 1 and half years from December 1997 to April 1999. Under this TA, a symposium was held in the Maldives in March 1998 involving government officials, judges, consultants, private lawyers, and ADB staff. The primary focus of the symposium was on establishing an institute of law.

The first TA demonstrated the following needs: for lawyers to be trained in modern commercial law, as the existing educational institute in the country - the Institute of Islamic Studies (IIS) - focused on aspects of shari'ah and its programs did not specifically deal with modern commercial and regulatory matters needed by a developing country; for indigenous capacity in legal education and training; and for improving court administration and procedures by providing training to island

21 These reasons are given in the TA completion report for this project at http://www.adb.org/Documents/TACRs/MON/30539-MON-TACR.pdf (last visited 18 December 2006).

22 ADB. 2002. Technical Assistance to Mongolia for the Retraining of Legal Professionals in a Market Economy II (TA No. 4077-MON).

23 ADB TA No. 2896-MLD: Strengthening the Maldivian Legal System. There is no TA completion report for this project as under ADB's procedures, no such report is required for TAs of US $\$ 150,000$ or less. 
magistrates and new recruits as well as in-service training to existing judges. A further grant assistance, which ADB provided in December 1999, in its second TA for Strengthening Legal Education and Judicial Training (TA No. 3389-MLD), was therefore provided to address these needs.

\section{STRENGTHENING LEGAL EDUCATION AND JUDICIAL TRAINING IN THE MALDIVES}

In late 1999, Maldives had no post-secondary education institute offering legal training or education. ${ }^{24}$ At that time, the country with its population of about 270,000 had 71 legal practitioners, of which only three were female, registered with the Ministry of Justice (MOJ) to practice law. Twenty-one of them had a law degree from a foreign law school while others were trained under programs provided by MOJ or by the IIS. The Maldivian legal system is based on Islamic law, with admixtures of English common law primarily in commercial matters. ${ }^{25}$ In 1995, IIS replaced its mohamee (lawyer) and qazee (judge) courses with a 3-year diploma course for students wishing to be judges or lawyers, but these courses were given by part-time lecturers including the President, the Chief Justice, the Attorney-General, and eminent private practitioners. There were no courses for some years as there were no suitably qualified full-time teachers, and there were constraints on the existing part-time lecturers and space.

The government's Fifth National Development Plan (1997-2000) supported the establishment of a law institute in the country to ensure the efficiency of the judiciary by improving the court procedures, providing professional training to judiciary members, and upgrading the skills of the island court magistrates. The government established ISL in August 1999, whose main functions included formulating and conducting education and judicial training in shari'ah and law, including continuing legal

24 English medium schools were introduced by the government in 1960 resulting in an additional form of education system to the traditional system where Dhivehi and Arabic were taught. 
education, for lawyers and judges; and conducting short-term courses for government officials, business community, and the public. In November 1999, there were 44 vacancies in the island courts and there was a pressing need to train new recruits. The judicial system in Maldives has a 3-tier court system: the lowest tier has 201 first instance trial courts administered by MOJ of which 4 are located in Male (the capital of Maldives and the most populous part of the country) and the rest in the inhabited islands (about 198 islands); the middle tier is the High Court in Male which consists of the Chief Justice and 4 other judges; and the highest tier is the President, who is given the highest authority in the administration of justice under the Maldivian constitution.

The Project aimed to strengthen the institutional capacity of FSL to deliver legal education and judicial training through 2 components: legal education and judicial training. The legal education component covered the following activities: curriculum development for a fledgling faculty; capacity building to support the dean and deputy director in administration and budgeting; collecting Maldivian legislation and translating them into English and producing textbooks and teaching materials in Dhivehi; organizing a cadre of FSL professional staff - 3 law lecturers and a librarian - through training and fellowship; providing equipment and legal resource materials for the library; providing local resource persons to present lectures or courses; and having a linkage arrangement with a suitable foreign institution. The judicial component covered the following activities: carrying out judicial training activities for judges and island magistrates including the production of a judicial bench book and training on the use of this book; a study tour for selected judges on the organization and delivery of judicial training and commercial law; a judicial training program for 44 new island magistrates; and provision of local resource persons to present lectures or courses. As this is the first LPR project carried out by ADB which involves application of shari'ah and common law, challenges were posed in getting the "right" consultants who know and can apply both shari'ah and common law.

The Project had various stakeholders with varying roles. The government's Ministry of Finance and Treasury (MOFT) was the project executing agency, the key government stakeholder involved in decisionmaking processes. In most of ADB's TA projects in the Maldives, MOFT has typically been the project executing agency to effectively both lead aid coordination and expedite project implementation. The Maldives College of Higher Education (MCHE), acting through FSL, was the 
implementing agency carrying out the Project in coordination with the Attorney-General's Office (AGO) for the legal education component and MOJ for the judicial component. FSL was physically located in MCHE premises and this afforded easy access for MCHE to provide guidance to FSL whenever needed.

MOJ's functions covered the administration of all courts other than the High Court (which directly reports to the President), registering lawyers practicing before the courts, and carrying out all matters related to the administration of justice not entrusted to the High Court. MOJ played a crucial role in determining the needs of the island magistrates for formal training especially the vacancies arising in the island courts and for in-service training for judges and island magistrates. AGO played an important role in determining the curriculum development at FSL, hiring students who graduated from FSL, and facilitating the use of materials at the new national law library established in 2004 to be used as an additional resource center facility for FSL students. FSL by virtue of its incipient existence was dependent on a core staff: the Director of FSL (renamed Dean, FSL in February 2001) to run the day-to-day operations, including lecturing; the Deputy Director who handled academic matters (and who was assisted in 2002 by an administrative officer); and an Assistant Director responsible for organizing the judicial training programs.

The TA project period was intended to be about 2 years from April 2000 to April 2002 but the project completion was in January 2004, after a delay of 21 months. ADB staff administered the Project including supervising the consultants engaged under the Project and fielding review missions at least annually from 2000 to 2003. Consulting services were engaged for each component, 2 years for the legal education component and 10 months for the judicial training component. The legal education component had three individual consultants (two foreign, one of whom was Mr. Ayus as the consultant team leader and advisor to FSL, and one domestic) while the judicial training component was carried out by a foreign consulting firm, which included one domestic consultant. 


\section{HANDLING MAJOR PROBLEMS UNDER THE PROJECT}

The Project faced 4 major problems. ${ }^{26}$ First, human resource constraints in the country within the 2-year period from April 2000 to April 2002. The project completion was in January 2004, after a delay of 21 months. Human resource constraints included a difficulty in identifying suitable personnel for the fellowship program as FSL lecturers. The appointment of candidates for the three fellowships for lecturer positions by the government was not done at the time when the consultants were fielded as provided in the project design so that the fellowships would have been completed before the consultants ended their terms. This required an extension of the legal education consultants for them to mentor the graduates when they completed their fellowships. The period of the consulting services was extended by 17 months. It was fortuitous that there were funds available under the Project to provide for the extension. The extension also gave the opportunity to the consultant team leader to set up and refine the curriculum development suited to indigenous conditions, including business law and environmental law, as well as work on a suitable linkage arrangement.

A second problem was identifying appropriate fellowships for the lecturers and the assistant librarian which resulted in the fellowship program for the professional staff at FSL running over the original timeframe. The educational background of the candidates was a factor that had to be taken into account in finding suitable fellowships. Also, in another case where the postgraduate fellowship was in place, the candidate who had been trained in Islamic law in his undergraduate studies had difficulties at postgraduate level to switch to studying the common law system. More time was needed to give allowance for this adjustment. The three postgraduate fellowships were provided in universities in Malaysia (two for the Masters in Comparative Law degree) and in the

$26 \quad$ Minor problems, usual in any project, also arose. Examples were delays in getting the TA letter agreement signed between ADB and government of Maldives, resulting in the fielding of consultants in August 2000, 4 months later than the original planned schedule of April 2000, and the renovation of FSL premises in 2001 instead of 2000 though this did not affect the legal education component as the consultants were able to work from the temporary premises provided by the government. 
United Kingdom (Masters of Law degree). The assistant librarian was provided with a fellowship to undertake a diploma in library and information management at a university in Australia.

Third, changes were made to the special judicial program, which was completed on time in December 2000, by MCHE's Faculty Advisory Committee. The change was to increase the original 6-month period to 12 months (subsequently extended to 16 months), which resulted in the introduction of a Certificate of Justice Studies (CJS) course at FSL in September 2001. The change was required by the government to fully equip the candidates who were trained to be island magistrates with sufficient academic knowledge in law and shari' ah given at FSL for 10 months (2 semesters), and the 6-month vocational training conducted at MOJ to equip them with magisterial and administrative skills. This was a departure from the original project design but reflected the local needs to ensure a suitable pool of trained persons to be island magistrates.

The minimum age requirement of 25 years for a judge as required under the Maldivian constitution had to be met. ${ }^{27}$ Maldives has a very young population with more than $43 \%$ under the age of $14 .{ }^{28}$ The minimum entry requirement to the CJS course is " $O$ " level certificate. The candidates have to be 25 at the date of appointment to the judiciary, that is, when they completed both the course at FSL and the training at MOJ.

The change, obviously, required more consulting inputs under the legal education component to carry out the curriculum development for the CJS course as the consultants for the judicial component had already ended their work. The government in August 2001 provided a judge of Male civil court to be the deputy director (judicial training) at FSL to coordinate the CJS course. Before the end of December 2003, 27 persons were appointed as island magistrates. The remaining vacancies would be filled by December 2004 by 1 graduate who could not assume the position till he satisfied the minimum age requirement of 25 years, and by the rest who would have completed the next CJS course.

$27 \quad$ Article 119 of the Constitution states: “a judge of a Court must be a person who has attained 25 years of age" and "has the necessary educational qualifications and competence to discharge the duties and the responsibilities of a judge.”

28 See https:/www.cia.gov/cia/publications/factbook/geos/mv.html (last visited 18 December 2006). 
Fourth, the duplication of activities by the IIS with those carried out by FSL was a long-standing issue as this had ramifications on the establishment of FSL as the most cost-effective solution and on FSL's sustainability. At the time of the TA preparation and approval, the government had agreed to transfer the diploma course in shari'ah and law from IIS to FSL upon commencement of FSL's teaching activities. Under the legal agreement for the Project, ADB can suspend or, after consulting the government, terminate the TA if any circumstances arise which in its opinion "interfere or threaten to interfere with the successful implementation of such Technical Assistance, the accomplishment of its purposes, or the execution of such Technical Assistance in accordance with the terms and conditions of this Agreement or the TA [letter agreement]." 29 This issue was followed up by ADB with the government periodically during the TA, including TA review missions from 2000 to 2003 when it was satisfactorily resolved. To have the TA suspended or terminated could have been an option but that would not necessarily have been the best option as the TA implementation was otherwise proceeding well and would have derailed the positive aspects of the completed activities.

Both ADB and the government agreed that with FSL's curriculum and use of English as the medium of instruction, FSL graduates had the advantage in handling international commercial transactions, and that there was a growing demand by both the public and private sectors for these law graduates to meet the country's economic development activities. The government assured ADB on its long-term resolution to avoid duplication of activities to ensure efficient use of limited resources in the country. Also, with MCHE's transfer from the Office of the President to the Department of Higher Education and Training in the Ministry of Education in November 2003, IIS would concentrate on Islamic studies while FSL would focus on shari'ah and law.

The legal agreement consisted of both the TA letter agreement for this Project signed between ADB and the government in February 2000 and the accompanying TA Framework Agreement between ADB and the government signed in October 1995 which is made applicable to the TA letter agreement. Paragraph 5 of the Schedule to the TA Framework Agreement between the government and ADB of October 1995. 
The above problems were solved with effective decision-making by the MOFT as the project executing agency with the Executive Director's personal attention to resolution of difficult issues. These positive actions ensured that bottlenecks were addressed and removed with timely interventions.

\section{GAINS FROM THE PROJECT}

Concomitant with major problems arising during project implementation, there were 6 gains from the Project in strengthening the institutional capacity of FSL. The gains are the preparation of a judicial bench book; development of a core cadre of professional staff (lecturers and librarian) at FSL; establishment of a suitable linkage arrangement; translation of Maldivian legislation into Dhivehi; provision of legal materials and computers in the faculty library; curriculum development for FSL; and the benefits from receiving a legal education. These gains are described in this section and the next 2 sections.

The preparation of a judicial bench book was a milestone event as it was the first production of its kind in Maldives. This bench book of July 2001 was published in both Dhivehi and English and provided to all judicial officers in the country, including the island magistrates. The statement of the Minister of Justice Ahmed Zahir in prefacing the bench book speaks for the usefulness of this production: "This book will be of much help in conducting cases submitted to the courts and also it would facilitate judges to find out the necessary statues, rules and regulations applicable in Maldivian courts. It would be easy to identify the procedure that has to be followed and the relevant action that is required to take in the individual cases, with the help of this book." ${ }^{30}$ The bench book would serve as the common platform in ensuring that the same approaches on the fundamental aspects of law and court procedure are being applied by the judges in performing their duties in the court on a day-to-day basis. This book covers the court system in Maldives, the roles of the judge and the advocate, judicial ethics for judges, court procedures, case

$30 \quad$ Benchbook: A Practice Manual for Judges, published by the Ministry of Justice, Republic of Maldives, 2001, Statement of the Minister of Justice dated 15 July 2001, p. i. 
management, and general law on three most common matters handled by judges (commercial law, property law, and criminal law). The bench book was translated into Dhivehi by the local consultant (judicial training assistant coordinator) and had inputs from the Ministry of Justice, senior judges, and a core faculty of judge trainers trained under the Project.

The development of a core cadre of lecturers and staff (three assistant lecturers and an assistant librarian) and additional lecturers at FSL was a positive development as it ensured that the faculty could effectively provide legal education at the end of the TA period without further need of consultants. Although the placement of the fellowships took a longer period and process, the long and patient wait paid off. Arrangements were also placed to ensure that the persons awarded the fellowships work full-time in FSL for a minimum of five years, to ensure sustainability of the faculty. Additionally, the government provided additional staffing of two lecturers as of January 2004 and agreed to place two additional lecturers in 2006/2007 as part of its continuing commitment to ensure FSL's sustainability.

The establishment of a linkage arrangement was a significant hallmark under the Project. The original TA design contemplated that a linkage arrangement with a suitable foreign institution would be worked on by the consultant team leader as part of the terms of reference. Efforts were made by the team leader to have linkage arrangement with various suitable institutions, including IIUM in Malaysia and other universities in countries that the government would find acceptable. While it was agreed that a linkage arrangement would be suitable to ensure sustainability, framing and a viable arrangement proved to be one which required time, patience, and the production of an acceptable academic performance resulting from FSL's programs such as the Advanced Diploma in Shari'ah and Law (ADSL). IIUM sent delegations to Maldives to check on the quality of the legal education by assessing and evaluating the process relating to FSL's application for the recognition of the ADSL program to be considered as an equivalent qualification for admission to the law faculty (kulliyyah) at IIUM and for the transfer of credits of subjects offered in the ADSL program. Visits were also made by MCHE and FSL authorities to IIUM to discuss the best form of linkage arrangement. Out of the four ADSL graduates of 2002, three continued their studies at IIUM to get a bachelor of laws degree while the other worked as a legal assistant in the Attorney-General’s Office. 
Under the legal education component, all Maldivian legislation in Dhivehi language were collected and placed in the FSL library. The senior lecturer consultant worked on collecting Maldivian legislation ${ }^{31}$ which had been translated into English by various government departments, private legal firms, and individuals and computerized 12 items of Maldivian law translated into English which were placed in a CD for FSL use as well as for the government's use. Not all the laws could be computerized into the $\mathrm{CD}$ as permission had to be obtained from appropriate authorities for computerization and for some legislation and regulations, the source of the translation could not be identified or permission was not given. The CD is helpful to the Maldivian public and to students accessing the FSL library, which was also stocked with legal materials made available through funds under the TA, as well as from other sources such a bilateral aid. The installation of computers in the library resulted in a computer:student ratio of 1:5 which enabled students to have easy access to legal materials on the internet, in Arabic, Dhivehi, and English.

\section{CURRICULUM DEVELOPMENT}

Curriculum development for FSL was a critical objective under the legal education component. It required a fresh look at how the incipient faculty would handle subjects and develop course outlines for students and for the longer-term growth of legal education in the country, while ensuring that the courses took into account indigenous needs. The curriculum development was handled by the consultant team leader in designing and preparing law subject outlines with help from the senior lecturer on shari'ah subject outlines and the local consultant on local law which required shari' ah inputs. The following law outlines were developed: general principles of law for the Certificate of Shari'ah and Law (CLS) course; and constitutional and administrative law, contract law, tort law, company law, criminal law, business law, international trade and shipping law, land law, and Islamic commercial law for ADSL. The shari' ah subject outlines prepared were Islamic legal system and general principles of

The range covered was wide and covered 17 items of legislation including the Maldivian constitution, commercial law such as company law and negotiable instruments, and environment protection and preservation. 
shari'ah for CSL, and Islamic legal system, family law, principles of Islamic jurisprudence (usul al-figh), Islamic law of succession, Islamic criminal law (jinayat), and Islamic commercial law for ADSL. Outlines for subjects which required local law and shari' ah inputs were also prepared for the Maldivian legal system for CSL and ADSL; constitutional and administrative law, company law, criminal law, and land law for ADSL. The curriculum development was enhanced with inputs from MCHE, by including psychology in ADSL course so as to enrich the students with proper understanding of society and its behavior, and its relation to law and shari'ah.

The curriculum was a unique combination of two disciplines: common law and shari'ah. This approach was very pertinent to suit the local conditions and so far as the local circumstances render necessary. Maldives is a Muslim country and its legal system is predominantly based on shari'ah with admixtures of English common law primarily in commercial matters. Economic development in the country demands that legal professionals, lawyers and judges alike, be better equipped in commercial and financial laws and regulations. Shari'ah graduates may be constrained in these areas but law graduates with common law education are exposed to these laws and regulations but are not wellequipped with shari' ah principles and local laws. Hence, the introduction of the curriculum was a step in addressing a suitable composition in offering a basic but comprehensive legal education appropriate for the country's needs. Prior to the setting up of FSL, the IIUM was the institution attended by most Maldivian students who wished to have both law and shari'ah education as a dual legal education was offered at costs that were reasonably affordable. Many IIUM law graduates on their return to Maldives were successful in pursuing professional careers by setting up their own legal firms and working on international financial and commercial transactions; by working in government offices such as AGO; by serving as judges of the Male Court; or by working in the private sector.

Against this background on the need to have a dual context of law and shari' ah and the suitability of IIUM legal education, the curriculum designed for FSL was modeled on the curriculum which had been successfully introduced and applied at IIUM since 1983 . The inputs by local legal professionals as part-time lecturers also contributed to the development of in-house and localized curriculum suited to Maldivian needs. The Certificate in Shari' ah and Law course (a foundation course 
equivalent to Advanced-level, pre-university admission standard) was taken over from FSL and run by MCHE in January 2003 as foundation course for all other disciplines came under the general administration of MCHE, following the trend set by most universities around the world to offer in their respective faculties diploma and degree courses and not foundation courses. FSL lecturers in shari'ah and law, however, continued to participate in teaching the foundation subjects related to law and shari'ah in contributing to the overall legal education in the country.

\section{BENEFITS FROM RECEIVING A LEGAL EDUCATION}

The authors carried out interviews with a number of persons from the Maldives connected with the Project including the present Dean of FSL, former FSL staff, FSL graduates, and legal practitioners on the benefits of the Project to FSL and the legal profession. The authors noted that overall these students benefited from the legal education in several ways. There were also other trickle-down effects such as the increase in numbers of female students who were given learning opportunities at FSL and had work opportunities or further legal education options open to them after graduating from FSL.

First, there was an increase in the number of legal practitioners in the country. For the first time in the Maldives, a legal education at ADSL level in shari'ah and law was offered to students. During the TA period, 3 ADSL courses were carried out resulting in 28 graduates (14 females and 14 males). The first ADSL course had 4 graduates ( 3 females and 1 male), the second had 11 graduates ( 6 females and 5 males), and the third had 13 graduates ( 5 females and 8 males). As of 18 December 2006, FSL has produced a total of 52 ADSL graduates (23 males and 29 females) which indicated the number of students, including female students, interested in pursuing a legal education in shari'ah and law when one considers that at the start of the TA period, there were 71 legal practitioners in the country, of which only 3 were female. The majority of ADSL graduates are registered lawyers. As of 18 December 2006, there are 272 lawyers registered with MOJ out of which 82 are females. ${ }^{32}$

32 The figures are from the Ministry of Justice of Maldives website at http://www.justice.gov.mv (last visited 6 December 2006). The website is in Dhivehi and the figures have been verified. 
Second, a comprehensive legal education in the country through the introduction of a Bachelor of Law (LL.B) degree was provided. In the Maldives, an ADSL qualification would be sufficient for the candidate to be registered with MOJ although in the long run, ADSL would not be sufficient for the purpose as it still falls short of a bachelor degree and does not offer a comprehensive legal education typically offered under a degree course. Towards the end of the TA period, the lead consultant recommended to MCHE to introduce a Bachelor in Shari'ah and Law (BSL) degree program (subsequently renamed as LL.B degree) as it was FSL's primary activity to produce qualified persons to become members of the legal profession. To enable a candidate to enter the legal profession, like those in common law countries, such as in Malaysia and Singapore, either as a legal practitioner or a judicial officer, the person is required to have certain qualifications before being allowed to practice law in the country as an advocate or solicitor. For example, in Singapore, the person would, before 1 May 1993, have to pass the final examination leading to a degree (LL.B) from a recognized university, or a barristerat-law or solicitor of England, or in possession of other degree or qualification as may be declared by the government and has obtained a certificate from the Board of Legal Education, to make the candidate a qualified person for the purposes of the legal profession. ${ }^{33}$

Some ADSL graduates who obtained the required grades could continue to read law up to the degree level (LL.B) at IIUM under the linkage program between MCHE and IIUM when the recognition and transfer of credits under the ADSL course was granted by IIUM in June 2004. Through this linkage program, credit transfers from ADSL are granted by IIUM to enable ADSL graduates to complete their LL.B programs earlier and with lesser subjects to study. However, those who could not achieve the required grade for admission to the linkage program or those who are qualified but do not have the financial means to continue their studies abroad would miss the opportunity. To fully equip and professionally qualify the graduates in legal education and training, FSL and MCHE decided to endorse the lead consultant's recommendation and extended the ADSL course to 3 years; and to confer on successful graduates the LL.B degree. (last visited 18 December 2006). 
The additional 1-year study was introduced in January 2004 covering vocational and professional practice subjects to enable the 2year ADSL graduates (who had completed the academic stage of the studies) to continue their studies further for the LL.B degree locally. Fresh 2004 intake students were allowed to register for the new 3-year LL.B degree course and may later opt to receive ADSL, after 2 years, if they then decide to join IIUM for their LL.B course. The students can register for the 3-year LL.B course at FSL, with an option to receive the ADSL certificate at the end of the second year, instead of staying another year at FSL. The curriculum for the first 2 years remains the same as in ADSL. The rest of the subjects to be studied in the third year are vocational and professional practice subjects. The lead consultant in collaboration with local practitioners designed the curriculum and course outlines for this additional 1-year study which covered Maldivian law of evidence and procedure, shari'ah evidence and procedure, law of evidence (common-law based), equity and trust, alternative dispute resolution, jurisprudence, and co-curriculum activities such as mooting and a 6-week attachment at the High Court, MOJ or other ministries, AGO, or legal firms.

With the introduction of the additional 1-year study in 2004, 9 students graduated with an LL.B. degree, including 1 ADSL graduate of the first batch (2002) who did not have the opportunity to join the linkage program at IIUM. In 2005, 13 students graduated with the LL.B degree. As of December 2006, FSL produced a total of 52 ADSL graduates (23 males and 29 females) and 33 of these graduates (15 males and 18 females) have continued their studies for another year and graduated with the LL.B degree.

Third, the introduction of the LL.B degree in turn provided further learning opportunities for the law graduates including pursuing postgraduate studies. FSL's LL.B degree has been recognized by some countries for the purpose of admission to postgraduate studies in law, for example, Australia, Malaysia, Malta, Singapore, and the United States. The recognition stems from the good curriculum development and structure of course work in the ADSL and LL.B programs. In 2005, a female FSL candidate who graduated with ADSL in 2003 and LL.B in 2004 was admitted to the Master in Comparative Laws (MCL) program at IIUM. She is expected to graduate in the 2006-2007 academic session. Prior to joining IIUM, she was recruited as an assistant legal officer at MOJ, earning a triple promotion from her previous position as a secretary. 
Another female graduate (graduating with CSL in 2001, ADSL in 2003, and LL.B in 2004) has gained admission to IIUM's MCL program in November 2006, and has deferred her admission to July 2007. Currently she is with the AGO. Another female graduate (graduating with ADSL in 2002 and LL.B. in 2004), who is also a legal officer at the AGO, is currently pursuing a masters law degree in Malta. Another female graduate, graduating with CSL in 2001, (ADSL in 2003 and LL.B. in 2004) was awarded a Fulbright scholarship and is currently pursuing a Masters degree in international law and human rights at the University of Pennsylvania, USA. She was initially offered a place to do a Masters course at the National University of Singapore, but she could not take up this offer due to lack of financial assistance. After her graduation from FSL, she chose to join FSL as an academic staff, despite having received many job offers from law firms, AGO, the Law Commission, and the Bank of Maldives.

Fourth, there are increased work opportunities for FSL graduates. Typically, graduates practice law and join the government, private law firms, or private sector. The authors note that the quality of the graduates is acceptable and appreciated by employers in Maldives. For example, the former Attorney General informed that he was satisfied with all the 4 graduates of the first ADSL, 2 of whom were working in the AGO and the remaining 2 in government ministries which have dealings with AGO. The former Attorney General in his capacity as the President of the Law Society of Maldives also stated the Law Society was pleased with the quality of these graduates and that the private sector lawyers were keen to absorb ADSL graduates given the quality of education at FSL. Several police personnel who had joined FSL and graduated with CSL, ADSL and LL.B. are now working in better positions in the force. One of them is heading the criminal investigation team, and another was promoted as a trainer in the training division. All the graduates who have been interviewed have expressed their satisfaction that the qualifications they obtained from FSL are recognized in Maldives both by the government and by the private sector and outside Maldives for further education by foreign universities and educational institutions. Many have also expressed their desire to pursue a higher degree if they had the financial assistance to do so, as some of them have actually obtained admission to postgraduate studies abroad but could not secure adequate funding. 


\section{LESSONS LEARNT}

There were many lessons learnt under this Project which have relevance not only for a follow-on project but also for future legal education and judicial training project in any developing country. There are no definitive general prescriptions of right or wrong approach; rather, the best approach seems to be one that has sensitivities to domestic issues and indigenous conditions, and qualities of patience, accommodation, and perseverance for fruition of outcomes. Lessons were learnt along the way during project implementation and there was a need to be flexible to meet challenges during the project's administration. There is, however, no blueprint for a legal education and judicial training project in term of a “one-size-fits-all approach.” The lessons learnt have been classified in 9 areas.

First, more time is needed to do preparatory work in determining the actual time period to carry out the Project. It took 17 months more to carry out the Project as events turned out. While there is no "rush for time" in these TA projects, extensions of completion dates should not be whimsical but be based on needs justifying such an extension. LPR activity takes time because it is more of a process than a project involving studies, e.g., carrying out feasibility studies for the construction of an investment project. The process involved is that of engaging with various stakeholders who may have evolving and different ideas on implementing specific activities, e.g., developing the special judicial training course with induction and skills development training best suited to the local context. It also explains why legal and judicial reform projects are slow and not easy to achieve all the desired results within a quick time frame. Legal and judicial systems are created over time and change in response to circumstances, and it cannot be expected that an intervention by a multilateral development bank be insensitive to the need to respond to local circumstances.

Second, there must be a conscious need to factor the local context in the TA project, both during the design and during execution, and employ a flexible approach in implementation. A lesson learnt from the law and development movement in the 1960s and 1970s is that there should be an analysis of the local conditions before imposing a western style legal system approach. In this case, a dual legal system was considered shari'ah and law - because it was best suited in the Maldivian context. It is also important to strike a fine balance between, on one hand, pursuing the project's objectives and, on the other hand, taking into account the 
country's considerations of development needs, constraints (such as limited human resources in identifying suitable personnel for the fellowship placements), the role of various government agencies, and the political sensitivities involved.

Third, use of local personnel helps to ensure ownership of the project by the country and the citizens. Maldivians were used to provide lectures or courses for the legal education component and the judicial training component, e.g., the Chief Justice, judges of the High Court, Attorney General, Minister of Justice, judges from Male courts and the islands, practicing lawyers and local shari' ah experts. They demonstrated their contributions and support to the project and evinced local ownership of the project. Experience shows that active involvement of legal professionals in civil society helps in contributing to the development of FSL and training of judges helps to ensure the "buy-in" of the project as they will "own" the project better as they realize that they themselves can do their part in contributing to the development of an indigenous law school producing good law graduates and to a more efficient judiciary.

Fourth, building up a good legal materials system in the library together with computers plays an important part in providing basic resource materials for faculty and students to access legal materials on the internet and enhance legal education. This system covers the law library (with funding provided under the TA) and contributions by the government, a bilateral donor, and Australian Legal Resources International. ${ }^{34}$ These materials are also available to other users of the faculty library thereby playing an important part in information dissemination. Legislation in Maldives translated into English under technical assistance projects can also be used by updating materials placed with organizations such as World Legal Information Institute ${ }^{35}$ which publishes legal information materials and provide both law professionals and the general public free internet access.

\footnotetext{
$34 \quad$ An Australian non-profit, non-government organization dedicated to the support of democracy, human rights, and the rule of law in developing countries.

35 WorldLII is a joint initiative of several university-based legal information institutes which provide free, independent and non-profit access to worldwide law. Its website is at http://www.worldlii.org/(last visited 18 December 2006).
} 
Fifth, having bonding arrangements, e.g., ensuring that the FSL professional staff returned to FSL, after completing their fellowships, to work full-time for a minimum period of 5 years and the judges selected for the judicial study tours resumed their positions for a minimum period of 2 years with a commitment to work with FSL in developing training programs, helped in ensuring that there is "carry over" and sustainability of legal education and judicial training. These arrangements have to be appropriately framed, taking into account the local government rules on service, for them to be workable.

Sixth, the government's commitment to the project and to the overall legal reform process is important not only for ensuring sustainability of the project but for future projects and importantly for the overall functioning of the legal system. The government's Fifth National Development Plan (1997-2000) and the Sixth National Development Plan (2001-2005) highlighted good governance as a key development objective, which includes the establishment of a modern public administration, a comprehensive and transparent set of laws, and an impartial and competent judiciary. ${ }^{36}$ ADB's Country Strategy and Program Update of August 2005 states that the country's long-term development priorities, including "supporting good governance, especially through improved public sector management efficiency, but also through legal and judicial reforms" ${ }^{37}$ are "unchanged," 38 despite the Asian tsunami which struck the Maldives in December 2004. ADB has also assisted the government in preparing its Seventh National Development Plan. It is important that LPR activities do not exist in a vacuum but in turn coexist and complement the government's immediate and long-term objectives in the same areas as such objectives are crucial for ensuring the long-term impacts of any LPR activity, which take time for trickle-down effects. The government's Agenda for Democracy, Human Rights and Reform of September $2005^{39}$

$36 \quad$ See ADB. Country Strategy and Program Update for Maldives (20022004) of July 2001 at http://www.adb.org/ Documents/CSPs/MLD/2001/ CSP MLD 2001.pdf, paragraph 20 (last visited 18 December 2006). See ADB. Country Strategy and Program Update for Maldives (20062008) of August 2005 at http://www.adb.org/Documents/CSPs/MLD/ 2005/CSP-MLD-2005.pdf, paragraph 8 (last visited 18 December 2006). Ibid., paragraph 8.

At http://www.presidencymaldives.gov.mv/publications/Democracy HumanRightsReformAgenda.pdf (last visited 18 December 2006). 
specifically mentions the establishment of the FSL as a milestone in social and economic development for the country and the 31-point proposals in this agenda include divesting the presidency of its role as head of the judiciary and the establishment of a Supreme Court presided by the Chief Justice. The government's Roadmap for the Reform Agenda of March 2006 - Ushering in a Modern Democracy of March $2006^{40}$ includes a key component of enhancing the independence of the judiciary and reorganizing the administration of justice. The graduates produced by FSL in its initial years and in the years to come, especially the increase in the number of female FSL graduates, will provide the new wave for the country in having its indigenous legal education system with suitable linkage arrangements to foreign institutions. These graduates, in turn, can contribute to the realization of the country's management of the democratic reform agenda.

Seventh, it is also important that the team players during the Project duration remain the same or if there are personnel changes, there is no radical shift in direction so as to maximize effective results.

Eighth, contrary to perceptions that a long-term resident advisor may be expensive or difficult to fill because of the rarity of qualified candidates, the TA benefited from the services of the consultant team leader (also advisor to FSL) who worked for an extended period of 17 months for a total period of 40 months, without incurring additional cost to the TA budget due to the modest amount paid instead of the budgeted amount which had to take into account the international rates applied by ADB. There was technical transfer in terms of the curriculum development being handed over and the guidance given to the host agency counterparts including MCHE, the Dean, FSL and the Deputy Director, FSL.

Finally, the Project has tangible benefits such as the delivery of legal education by a fledgling faculty, the production of graduates with legal education who can contribute to the economic development of the country, and a judiciary trained with a judicial bench book to administer justice and in-service training provided such as handling case-flow management. These process-based evaluation indicators are internal to

$40 \quad$ At http://www.presidencymaldives.gov.mv/publications/Roadmap for the Democratic Reform Agenda. pdf (last visited 18 December 2006). 
the project and can be ascertained. However, impact-based evaluation indicators which are external to the project such as the role of judicial performance, the confidence of civil society in the improvements to the rule of law and administration of justice and in the quality of legal education, and the sustainability of FSL, should also be addressed in the TA design though these impacts will be felt over a longer period of time and are beyond the original design of the TA.

The lessons learnt are offered as an opportunity for consideration in the design of any legal education and judicial training project in a developing country. The most salient feature is the need to consider and take into account the local context. While the first movement of law and development of the 1960s and 1970s failed, the second ongoing movement of LPR activity holds promise. It is not just a matter of funding resources but actually working with the government and agencies responsible in ensuring the realization of the project's objectives and enhancing the legal and judicial environment in the country. 